\title{
CRUSTICORALLINA GEN. NOV., A NONGENICULATE GENUS IN THE SUBFAMILY CORALLINOIDEAE (CORALLINALES, RHODOPHYTA) ${ }^{1}$
}

\author{
Katharine R. Hind ${ }^{2}$ \\ Department of Botany and Beaty Biodiversity Research Centre, University of British Columbia, Vancouver, British Columbia, \\ Canada V6T $1 \mathrm{Z4}$ \\ Paul W. Gabrielson \\ Biology Department and Herbarium, University of North Carolina, Chapel Hill, Coker Hall CB 3280, Chapel Hill, North Carolina \\ 27599-3280, USA \\ Cassandra P. Jensen, and Patrick T. Martone
}

Department of Botany and Beaty Biodiversity Research Centre, University of British Columbia, Vancouver, British Columbia, Canada V6T 1 Z4

Molecular phylogenetic analyses of $18 \mathrm{~S}$ rDNA (SSU) gene sequences confirm the placement of Crusticorallina gen. nov. in Corallinoideae, the first nongeniculate genus in an otherwise geniculate subfamily. Crusticorallina is distinguished from all other coralline genera by the following suite of morpho-anatomical characters: (i) sunken, uniporate gametangial and bi/tetrasporangial conceptacles, (ii) cells linked by cell fusions, not secondary pit connections, (iii) an epithallus of 1 or 2 cell layers, (iv) a hypothallus that occupies $50 \%$ or more of the total thallus thickness, (v) elongate meristematic cells, and (vi) trichocytes absent. Four species are recognized based on $r b c \mathrm{~L}, p s b \mathrm{~A}$ and COI-5P sequences, $C$. painei sp. nov., the generitype, C. adhaerens sp. nov., C. nootkana sp. nov. and C. muricata comb. nov., previously known as Pseudolithophyllum muricatum. Type material of Lithophyllum muricatum, basionym of $C$. muricata, in TRH comprises at least two taxa, and therefore we accept the previously designated lectotype specimen in UC that we sequenced to confirm its identity. Crusticorallina species are very difficult to distinguish using morpho-anatomical and/or habitat characters, although at specific sites, some species may be distinguished by a combination of morphoanatomy, habitat and biogeography. The Northeast Pacific now boasts six coralline endemic genera, far more than any other region of the world.

Key index words: COI-5P; crustose coralline algae; cryptic species; genicula; Northeast Pacific endemic; psbA; Pseudolithophyllum; rbcL; sequencing type specimens; SSU

\footnotetext{
${ }^{1}$ Received 27 March 2016. Accepted 9 July 2016.

${ }^{2}$ Author for correspondence: e-mail katharine.hind@botany. ubc.ca.

Editorial Responsibility: M. Vis (Associate Editor)
}

Abbreviations: AK, Alaska; BC, British Columbia; BI, Bayesian inference; bp, base pairs; BS, bootstrap; CA, California; COI-5P, cytochrome c oxidase subunit 1-five prime; EF2, elongation factor 2; ML, maximum likelihood; PP, posterior probability; $p s b A$, plastid-encoded gene of PSII reaction center protein $\mathrm{D} 1$; $r b c \mathrm{~L}$, plastid-encoded large subunit of RuBisCO; WA, Washington

Coralline algae (orders Corallinales, Hapalidiales, and Sporolithales) comprise a diverse group of calcifying red algae that are present in every ocean on the planet and play significant roles in marine ecology and nearshore carbon cycling (Littler 1972, Smith 1972, Foster 1975, Stearn et al. 1977, Paine 1984, Steneck 1986). Despite their ecological significance, basic questions remain about their systematics and biodiversity. Perhaps more than any other group of red algae, DNA sequencing is revolutionizing our understanding of coralline taxonomy from ordinal to species ranks (e.g., Bailey and Chapman 1998, Le Gall et al. 2010, Gabrielson et al. 2011, Martone et al. 2012, Kato et al. 2013, Nelson et al. 2015) and revealing species diversity in all biogeographic provinces that far exceeds what traditional morpho-anatomy had proposed (e.g., Hind et al. 2014b, 2015, Basso et al. 2015). While a taxonreplete molecular phylogeny is still lacking for these red algae, numerous taxonomic changes even at higher taxonomic ranks are expected.

Two predominant morphological types of coralline algae are recognized: geniculate taxa with crustose bases and alternating calcified and noncalcified erect segments (genicula), and nongeniculate taxa that lack segmentation and grow predominately as prostrate crusts or unattached rhodoliths. Beginning in the mid 19th Century, these two morphological types received formal taxonomic recognition as two 
tribes: Corallineae for the geniculates and Melobesieae for the nongeniculates (Areschoug 1852). This classification recognized the fundamental importance of the geniculum, which was continued by Johansen (1969) when he recognized three separate lineages of geniculate corallines: subfamilies Corallinoideae, Amphiroideae, and Metagoniolithoideae. In contrast, Cabioch (1971) emphasized the importance of cellular connections (cell fusions vs secondary pit connections) to group together, for the first time, geniculate and nongeniculate taxa in the same tribes and subfamilies, for example recognizing a geniculate tribe Amphiroae within the otherwise nongeniculate subfamily Lithophylloideae. Johansen (1969; fig. 32) indicated in a diagram that Corallinoideae evolved from crustose corallines, but he did not speculate about the specific origins of Amphiroideae or Metagoniolithoideae and continued to argue the fundamental importance of the presence of genicula to classify corallines (Adey and Johansen 1972, Johansen 1974, 1981). These diverging views of the evolution, and thus subfamily classification, of geniculate corallines were resolved when Bailey and Chapman (1998) sequenced nuclear small subunit (SSU) rDNA gene fragments for 35 coralline species from a range of subfamilies. They demonstrated, in agreement with Cabioch (1971), that genicula evolved independently in the three subfamilies recognized by Johansen and that each geniculate subfamily likely arose from different nongeniculate ancestors. This conclusion has since been supported by phylogenetic analyses based on additional markers (Bittner et al. 2011).

Common to both Johansen (1969) and Cabioch (1971) was the singular focus on the evolutionary progression from nongeniculate to geniculate corallines. Neither researcher ever proposed the reverse, that some nongeniculate corallines could be derived from geniculate ancestors. We now know, however, that dramatic reductions in geniculate fronds have occurred during coralline evolution (Martone et al. 2012), and in one case this resulted in a complete evolutionary reversal and return to the crustose state. Hind and Saunders (2013) used DNA sequences from three markers, COI-5P, psbA and EF2, to show that several NE Pacific nongeniculate species that they called Pseudolithophyllum muricatum (Foslie) Steneck \& R.T.Paine were nested within the tribe Corallineae of the subfamily Corallinoideae, a subfamily that, sensu Johansen (1969) but not Cabioch (1971), included only geniculate genera. The type species of Pseudolithophyllum Me.Lemoine, however, is P. fuegianum (Heydrich) Me.Lemoine (Silva et al. 1996), a species considered to belong in the subfamily Lithophylloideae based on morpho-anatomy (Lemoine 1913). Herein, we resolve the identity of P. muricatum and propose Crusticorallina gen. nov. to accommodate $P$. muricatum and three other undescribed nongeniculate species that belong in this genus, all endemic to the Northeast Pacific.

\section{MATERIALS AND METHODS}

Specimens. Specimens for sequencing and morphological examination were field-collected by hand with a hammer and chisel in the low intertidal zone or in the subtidal using SCUBA and preserved in silica gel. Vouchers were deposited in NCU, UBC, and $\mathrm{UNB}$ or were archival specimens from TRH and UC; herbarium abbreviations follow Thiers (2016). All specimen details, including collection information and herbarium accession numbers, are included in Table S1 in the Supporting Information.

DNA processing. Field-collected and type specimens processed by PWG, including preparation, extraction, amplification, and sequencing of the $r b c \mathrm{~L}$ gene followed Gabrielson et al. (2011); amplification of the $p s b \mathrm{~A}$ gene (trimmed to $836 \mathrm{bp)}$ followed Broom et al. (2008). Field-collected specimens processed by CJ, KRH, and GWS were extracted according to Saunders (2008). The mitochondrial cytochrome c oxidase subunit (COI-5P, $664 \mathrm{bp}$ ) was amplified using the primers GwsFn (Le Gall and Saunders 2010) and GWSRx (Clarkston and Saunders 2012); rbcL was amplified as a single fragment using primers F57 (Freshwater and Rueness 1994) and rbcLrevNEW (Kucera and Saunders 2012), and were sequenced with additional internal primers TLR1 and TLF5 (Wynne and Saunders 2012) to attain full bidirectional data. The $p s b$ A locus was amplified using primers psbAF1 and psbAR2 (Yoon et al. 2002). Additional new primers (forward psbA16F 5'-GAAAGACGCGAAAGCGCAAG-3', reverse psbA952R 5'-GGTTCGCTCTATTTAGGATGTCAG-3') were used when amplifying and sequencing Crusticorallina adhaerens to avoid contamination issues. The SSU gene (1459 bp) was amplified as a single fragment using primers G01 and G07, and was sequenced with additional internal primers G04 and G14 to attain full bidirectional data (Harper and Saunders 2001). PCR products were sequenced using standard methods on a 3730xl DNA Analyzer (Applied Biosystems, Foster City, CA, USA). All sequence fragments were edited and aligned using Geneious 7.1.7 (Kearse et al. 2012). Genbank numbers assigned to all DNA sequences are provided in Table S1.

Phylogenetic analyses. SSU rDNA (1,459 bp) and concatenated COI-5P, $p s b \mathrm{~A}$, and $r b c \mathrm{~L}(2595 \mathrm{bp})$ datasets were built using previously published sequences and novel sequences generated in this study (Table S2 in the Supporting Information). Sequence data were aligned using Geneious 7.1.7 (Kearse et al. 2012). Following Kato et al. (2011) partial SSU rDNA sequences that could not be aligned due to insertions/ deletions were removed from the analyses. Outgroup taxa for the SSU rDNA analyses were chosen from the order Sporolithales (Broom et al. 2008). For the concatenated analyses, outgroup taxa were chosen from the order Hapalidiales (Broom et al. 2008). Maximum likelihood (ML) analyses for both SSU rDNA and concatenated datasets were conducted using RAxMLGUI v1.5 (Silvestro and Michalak 2012). ML analyses were based on a model of evolution $(\mathrm{GTR}+\mathrm{I}+\mathrm{G})$ obtained in jModelTest version 2.1.1 (Darriba et al. 2012) with 1,000 bootstrap replicates and partitioned by both gene and codon. Bayesian posterior probabilities (PP) were generated using the program MrBayes v3.2 (Huelsenbeck and Ronquist 2001) using the $\mathrm{GTR}+\mathrm{I}+\mathrm{G}$ model and also partitioned by gene and codon. Both datasets were run for 6 million generations with a sampling frequency of 1,000 until convergence of independent chains was reached (average standard deviation of split frequencies $<0.01)$. Four Markov chains were used in our analyses. Burn-in was performed on the first $25 \%$ of trees generated, and were excluded from calculating PP.

Morpho-anatomical assessment. Morpho-anatomical characters informative for genus and species segregation in nongeniculate coralline algae were measured following 
Harvey et al. (2005). We use terminology for nongeniculate coralline algae (e.g., hypothallus, perithallus etc.) as per Johansen (1981). Pieces 5-10 mm long were cut from each sampled specimen and placed in $0.5 \mathrm{M}$ HCL for decalcification for 2-24 h depending on the specimen thickness. Acid was replaced every $30-60 \mathrm{~min}$ as needed. Specimens were then stained in $5 \%$ potassium permanganate for $30 \mathrm{~min}$, dehydrated in steps of $25 \%, 50 \%, 75 \%$, and $100 \%$ ethanol for $30 \mathrm{~min}$ each, and then placed in $100 \%$ medium grade LR White resin (London Resin Company, Reading, Berkshire, UK) overnight. Decalcified and stained specimens were oriented in gelatin capsules filled with LR White resin medium, placed in an oven for $3-4 \mathrm{~h}$ at $60^{\circ} \mathrm{C}-65^{\circ} \mathrm{C}$ until cured then sectioned (7-10 $\mu \mathrm{m}$ thick) with a Sorvall Porter Blum MT-2 Ultra-Microtome (DuPont Company, Wilmington, DE, USA). Sections were measured and photographed on an Olympus BX51WI compound microscope (Olympus, Tokyo, Japan) using an Olympus DP21 digital camera.

\section{RESULTS}

Molecular results. A phylogram was generated using SSU rDNA sequences for 22 representative coralline genera from each subfamily. ML and Bayesian inference (BI) analyses were conducted; their tree topologies were congruent, and bootstrap support (BS) and PP were appended to the ML tree (Fig. 1). Crusticorallina resolved as a monophyletic clade with moderate to strong support ( $\mathrm{BS}=76$; $\mathrm{PP}=0.99$ ) as sister to the lineage containing Johansenia K.R.Hind \& G.W.Saunders, Corallina Linnaeus and Ellisolandia K.R.Hind \& G.W.Saunders, subfamily Corallinoideae, family Corallinaceae (Fig. 1). SSU rDNA sequences were not able to differentiate Crusticorallina at the species rank (Appendix S1 in the Supporting Information).

Using DNA sequences from three gene regions (COI-5P, $r b c \mathrm{~L}, p s b \mathrm{~A})$ known to resolve corallines at the species rank, ML analyses were conducted for each gene region individually (Figs. S1, S2, S3 in the Supporting Information) and concatenated (Fig. 2). In each analysis four distinct genetic clusters were resolved with strong support $(B S=100$;

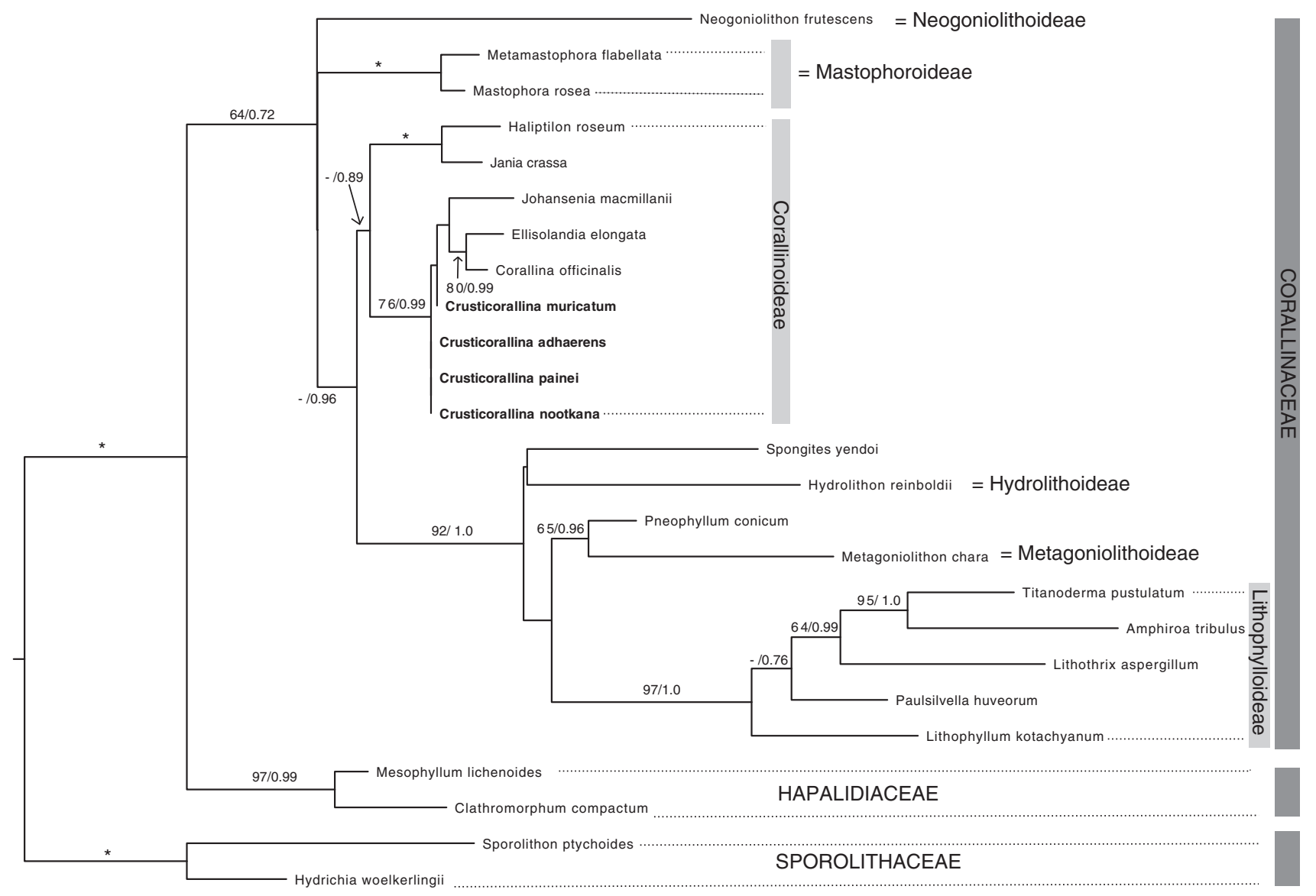

0.04

FIG. 1. Phylogram inferred by maximum likelihood (ML) analysis of SSU sequence data, demonstrating that Crusticorallina species fall within the family Corallinaceae, subfamily Corallinoideae. Support values are listed as bootstrap for ML analyses and Bayesian posterior probabilities respectively. Asterisks denote nodes that are strongly supported (bootstrap values $>98$, posterior probabilities $=1.0$ ) in all analyses. Support values are not indicated for all nodes (i.e., bootstrap values $\leq 50$, posterior probabilities $\leq 0.65$, or between closely related species). Scale bar refers to substitutions per site. GenBank numbers for SSU sequences are included in Table S2. 


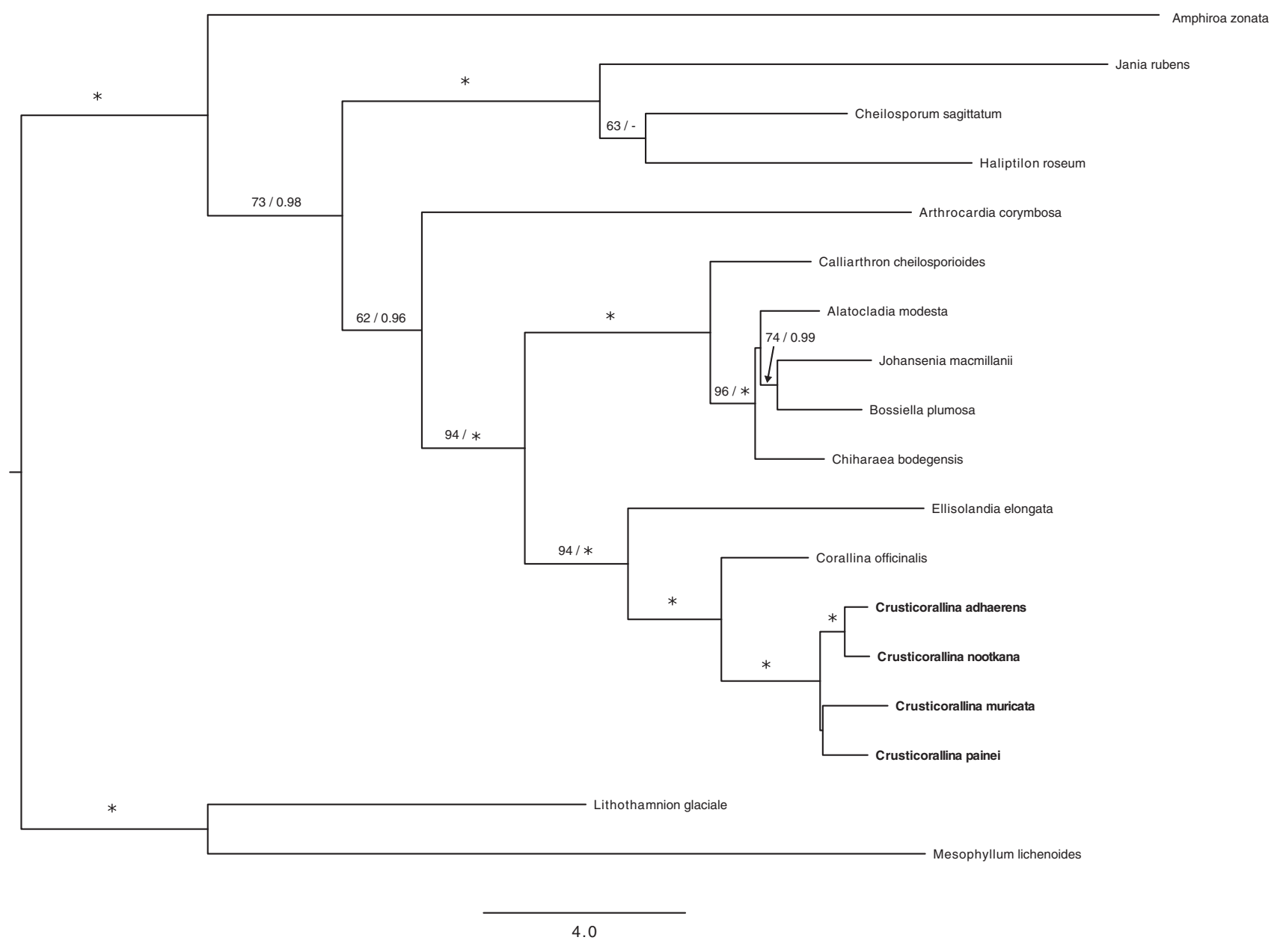

FIG. 2. Phylogram inferred by maximum likelihood (ML) analysis of concatenated CO1-5P, $p s b \mathrm{~A}$, and $r b c \mathrm{~L}$ sequence data. Support values are listed as bootstrap for ML analyses and Bayesian posterior probabilities, respectively. Asterisks denote nodes that are strongly supported (bootstrap values $>98$, posterior probabilities $=1.0$ ) in all analyses. Support values are not indicated for all nodes (i.e., bootstrap values $\leq 50$, posterior probabilities $\leq 0.65$, or between closely related species). Scale bar refers to substitutions per site.

$\mathrm{PP}=1.0$, in the concatenated analysis). Pairwise distance matrices support levels of differentiation indicative of species level divergence (for COI-5P, see Robba et al. 2006, for $r b c \mathrm{~L}$ see Gabrielson et al. 2011, for psbA see Broom et al. 2008) (Appendix S1) and the presence of a barcode gap (maximum intraspecific DNA sequence divergence is less than the minimum interspecific DNA sequence divergence). The name Crusticorallina muricata was applied to those specimens that matched partial $r b c \mathrm{~L}$ sequences of lectotype material of $P$. muricatum from UC (see below for more details). The other three species did not match any type specimen sequences from the NE Pacific and are newly described below.

Taxonomic and morphological results. Crusticorallina K.R.Hind \& P.W.Gabrielson gen. nov.

Etymology: crusti refers to the nongeniculate (crustose) morphology; corallina refers to its placement in subfamily Corallinoideae.
Diagnosis: nongeniculate coralline, relatively thick (total crust thickness 360-950 $\mu \mathrm{m}$ ) and encrusting; thallus construction monomerous with hypothallus comprising $50 \%-80 \%$ of total thallus thickness; epithallus of 1-2 cell layers; intercalary meristematic cells very elongate $(18-38 \mu \mathrm{m}$ long); cell fusions present, secondary pit connections absent; trichocytes absent; gametangial and bi/tetrasporangial conceptacles uniporate and sunken (Fig. 3, A-C).

Type species: Crusticorallina painei P.W.Gabrielson, K.R.Hind, G.W.Saunders, Martone \& C.P.Jensen sp. nov. We chose C. painei as the generitype of Crusticorallina to recognize and honor the work of the eminent ecologist, Dr. Robert Paine who worked extensively with Crusticorallina in the NE Pacific.

Comments: Crusticorallina species have been documented from central CA, USA through northern BC, Canada (Fig. 4), representing yet another northeast Pacific endemic coralline genus. In the field, specimens often - but not always - appear as 


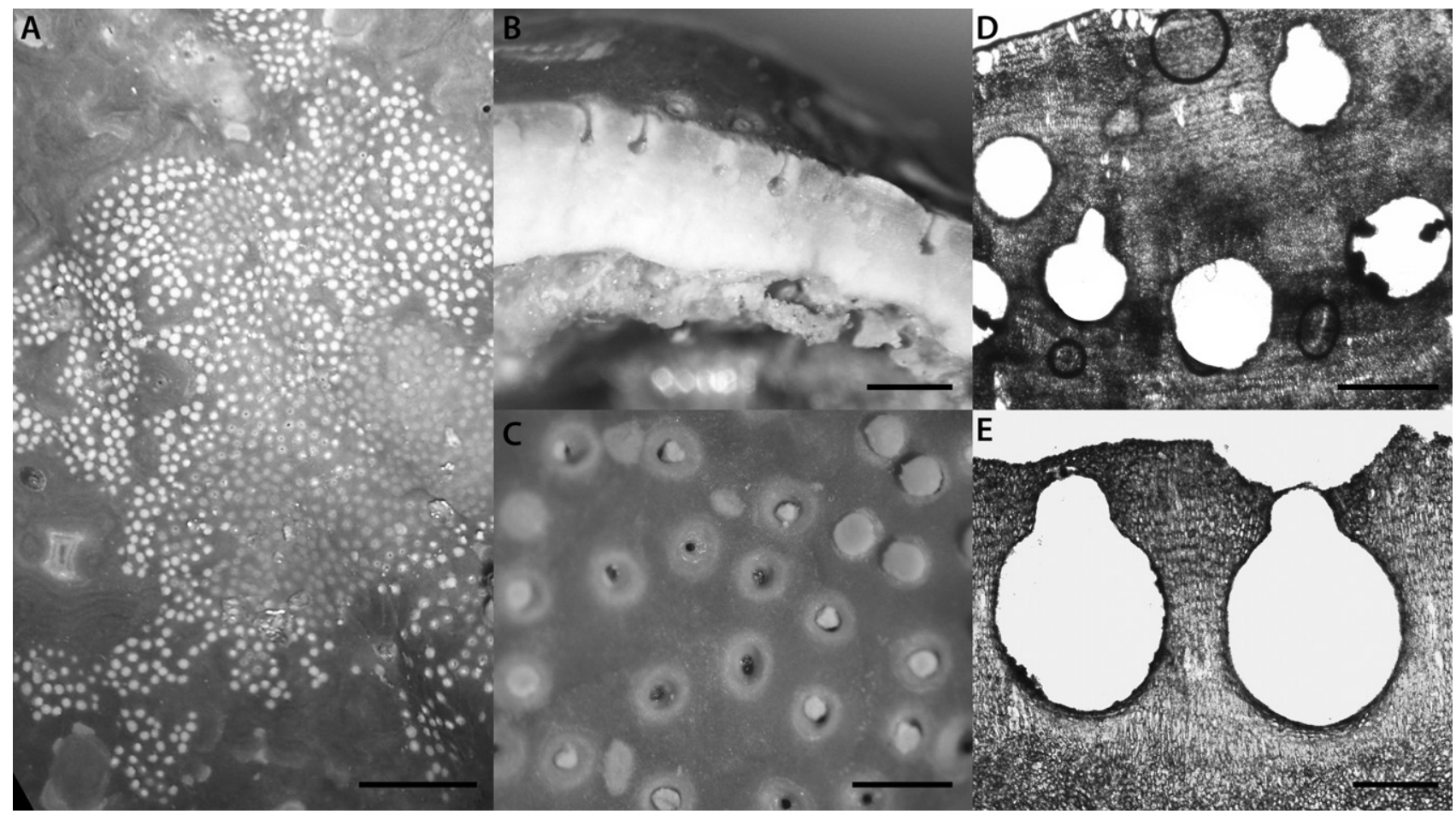

FIG. 3. Reproductive overview of Crusticorallina species, showing (A) patchy distribution of surface conceptacles (C. muricata, UBC A91424), scale $=1 \mathrm{~mm}$; (B) flask-shaped conceptacles with rounded bottoms and elongated canals (C. painei, GWS027973), scale $=0.5 \mathrm{~mm} ;(\mathrm{C})$ decalcification and plug dislodgement of uniporate, sunken conceptacles $($ C. muricata, UBC A91424), scale $=500 \mu \mathrm{m}$; (D) buried conceptacles from previous years (C. adhaerens, GWS019429), scale $=250 \mu \mathrm{m}$; and (E) sunken conceptacles near crust surface (C. adhaerens, GWS010847), scale $=100 \mu \mathrm{m}$.

thick crusts sometimes with wide white margins and/or superficial swirls (Fig. 5) growing in both subtidal and low intertidal habitats. Thin sections are required to observe the suite of characters that define the genus (Figs. 3 and 6), but rarely are any of these characters, even in combination, sufficient to differentiate species (Table S3 in the Supporting Information).

Crusticorallina painei P.W.Gabrielson, K.R.Hind, G.W. Saunders, Martone, \& C.P.Jensen sp. nov.

Etymology: Named after Dr. Robert Paine, a pioneer in intertidal ecology, who studied competition and other ecological interactions among nongeniculate coralline algae.

Holotypus: UNB GWS027973.

Type Locality: Lost Islands, SE wall, Gwaii Haanas, BC, Canada. Subtidal, $10 \mathrm{~m}$ depth, epilithic. leg. G.W. Saunders.

Description: Thallus encrusting, smooth, sometimes $(38 \%)$ with scattered white swirls (visible especially when dry, Fig. 5, A and E) to $650 \mu \mathrm{m}$ thick, white margin thin to prominent $(0.3-0.55 \mathrm{~mm}$ wide, Fig. 5E); epithallial cells $4.0-7.4 \mu \mathrm{m}$ tall, always flared distally to $6.3-7.6 \mu \mathrm{m}$ wide Fig. $6 \mathrm{I}$; perithallus 118-255 $\mu \mathrm{m}$ thick (Fig. 6E); hypothallus 297$444 \mu \mathrm{m}$ thick (Fig. 6A); conceptacles flask shaped with rounded bottoms (Fig. 3B), chambers $\sim 114 \mu \mathrm{m}$ wide $\times 107 \mu \mathrm{m}$ tall, and elongated canals $\sim 102 \mu \mathrm{m}$ long; $r b c \mathrm{~L}, p s b \mathrm{~A}$ and $\mathrm{COI}-5 \mathrm{P}$ sequences diagnostic (see Table S3, Appendix S1).

Habitat and Habit: Only found on bedrock in exposed habitats; occasionally in the low intertidal zone and common subtidally to $15 \mathrm{~m}$ depth.

Distribution: Haida Gwaii, BC, Canada south to Tatoosh Island, WA, USA (Fig. 4).

Comments. Biogeography and habitat together help differentiate Crusticorallina painei from other Crusticorallina species. Based on our collections, C. painei is a relatively northern species with the limited distribution as stated above (Fig. 4). Although C. painei specimens often morphologically resembled the other species (Figs. 5 and 6; Table S3), they were almost always subtidal (90\%) and only found on bedrock in wave- or current-exposed habitats.

C. adhaerens K.R.Hind, Martone, C.P.Jensen \& P.W.Gabrielson sp. nov.

Etymology: Named for its propensity to adhere and grow on a wide variety of substrata.

Holotypus: UBC A91415.

Type Locality: Thrasher Point, Calvert Island, BC. Subtidal (13 m), growing on coral. leg. K. R. Hind.

Description: Thallus thick (to $840 \mu \mathrm{m}$ ), encrusting, smooth (Fig. 5B, more frequently $(57 \%)$ with scattered white swirls (visible especially when dry, Fig. 5F); white margin absent to prominent $(0-$ 


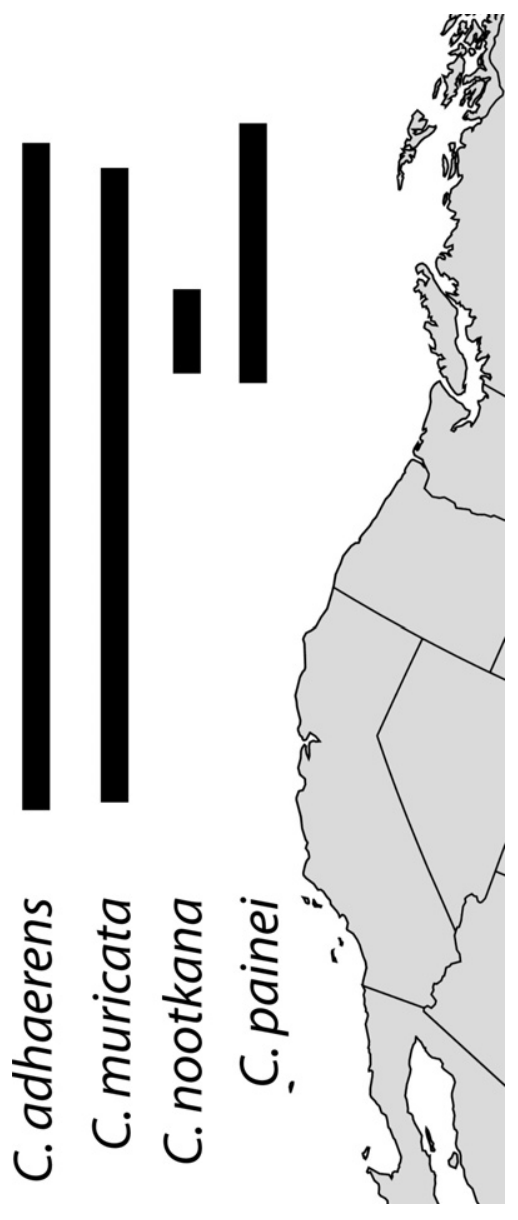

Fig. 4. Biogeographic distributions of Crusticorallina species in the Northeast Pacific

$1.25 \mathrm{~mm}$ wide) and rarely nonadherent; epithallial cells $3.6-8.3 \mu \mathrm{m}$ tall, always flared distally to 5.3$8.0 \mu \mathrm{m}$ wide (Fig. 6J); perithallus $121-300 \mu \mathrm{m}$ thick (Fig. 6, B and F); hypothallus 245-644 $\mu \mathrm{m}$ thick (Fig. 6B; conceptacles flask shaped with rounded bottoms (Fig. 3, D and E), chambers 190-236 $\mu \mathrm{m}$ wide $\times 200-227 \mu \mathrm{m}$ tall, and elongated canals 50$96 \mu \mathrm{m}$ long; $r b c \mathrm{~L}, p s b \mathrm{~A}$ and COI-5P sequences diagnostic (See Table S3, Appendix S1).

Habit and Habitat: Common on bedrock, rarely on cobble; epizoic on coral, sponge or mollusc; common subtidally to $20 \mathrm{~m}$ depth but also found intertidally, especially in low intertidal pools, on exposed shores and in more protected waters in the Salish Sea.

Distribution: Haida Gwaii, BC, Canada south to the Salish Sea and with an isolated population at Soberanes Point, Monterey County, CA, USA (Fig. 4).

Comments: C. adhaerens is often recognizable by its epizoic habit (once even found growing on glass bottle), but it also occurs epilithically (Fig. 5B) and then cannot be distinguished from the other Crusticorallina species. In particular, C. adhaerens is very similar in distribution (Fig. 4) and morphology
(Figs. 5, B and F; 6, B, F, J; Table S3) to C. muricata (Figs. 5, C and G; 6, C, G, K; Table S3), and thus it is possible that some of the field-collected material identified as P. muricatum in previous studies (e.g., Steneck and Paine 1986, McCoy 2013, McCoy and Pfister 2014) may have been this or another Crusticorallina species.

Crusticorallina muricata (Foslie) P.W.Gabrielson, Martone, K.R.Hind, \& C.P.Jensen comb. nov.

Basionym: Phymatolithon muricatum Foslie, Kongelige Norske Videnskabers Selskabs Skrifter 1906 "1905(10)": 19.

Type Locality: Botany Beach, near Port Renfrew, Vancouver Island, BC, Canada.

Lectotypus: UC 341316.

Homotypic synonyms:

Lithothamnion muricatum (Foslie) De Toni 1924: 622.

P. muricatum (Foslie) Steneck \& R.T.Paine 1986: 224.

Heterotypic synonym:

Lithophyllum lichenare L.R.Mason 1953: 339, Pl. 41.

Description: Thallus encrusting, loosely attached to the underlying substratum, both dorsal and ventral surfaces smooth, frequently undulating, as the crust follows the contours of the substratum, crust commonly 350-950 $\mu \mathrm{m}$ thick, frequently $(70 \%)$ with white swirls on the surface (visible especially when dry, Fig. 5G); white margin thin to prominent (0.35-0.7 mm wide, Fig. 5G); epithallial cells 4.1$8.5 \mu \mathrm{m}$ tall $\times 3.7-8.5 \mu \mathrm{m}$ wide, rarely flared distally (Fig. 6K; perithallus 77-424 $\mu \mathrm{m}$ thick (Fig. 6, C and G); hypothallus 282-646 $\mu \mathrm{m}$ thick (Fig. 6C); conceptacles flask shaped with rounded bottoms, chambers $68-152 \mu \mathrm{m}$ wide $\times 80-156 \mu \mathrm{m}$ tall, with canals 24-60 $\mu \mathrm{m}$ long; $r b c \mathrm{~L}$, $p s b \mathrm{~A}$ and COI-5P sequences diagnostic (See Table S3, Appendix S1).

Habit and Habitat. Epilithic, common on bedrock and overgrowing other encrusting corallines or kelp holdfasts. Rarely on cobble or epizoic; common in mid- to low intertidal zones and in pools and subtidal to $14 \mathrm{~m}$ depth on exposed shores and in more protected waters in the Salish Sea.

Distribution. Haida Gwaii, BC, Canada south to Malpaso Creek, Monterey County, CA, USA (Fig. 4).

Comments. Crusticorallina muricata is distinct from its congeners by the absence or rare occurrence of flared epithallial cells (Fig. 6K), a feature present in all of the other species. This species typically has a thicker perithallus, with no other species producing a perithallus greater than $300 \mu \mathrm{m}$ thick, and thus a thicker total thallus, with no other species growing thicker than $840 \mu \mathrm{m}$ (Table S3). Biogeography, habit, and habitat did not help distinguish C. muricata, as it occurs from Haida Gwaii, British Columbia, Canada through central CA, USA (Fig. 4), generally resembles the other species in the field (Fig. 5), and can be found both intertidally and subtidally (Table S3). Because of both its morphological similarity and overlapping distribution with its 
FIG. 5. Field photos of (A)

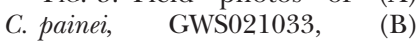
C. adhaerens, GWS021685, (C) C. muricata, GWS013078, and (D) C. nootkana, UBC A88650; wholemount thallus photos of (E) C. painei, GWS027973, (F) C. adhaerens, GWS012584, (G) C. muricata, UBC A91424, and (H) C. nootkana, GWS010093. Scale $=1 \mathrm{~mm}$.

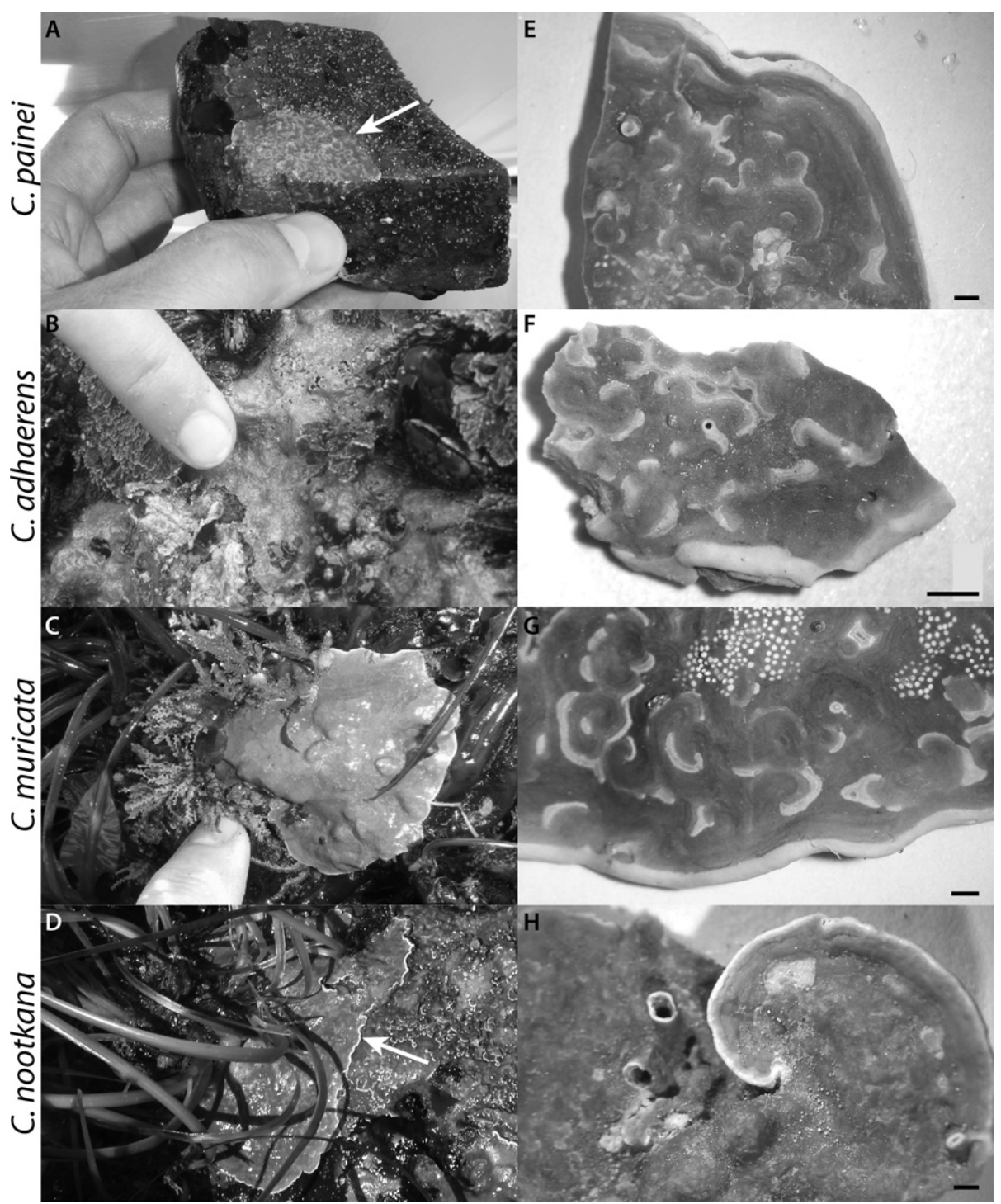

congeners, we based our description only on sequenced specimens. It is possible and even likely that previous studies on P. muricatum (Steneck and Paine 1986, McCoy 2013, McCoy and Pfister 2014) may have mistakenly included multiple Crusticorallina species.

Historical comments. Historically much confusion surrounds the application of this name because of three problems: the difficulty in circumscribing genera of nongeniculate corallines; the apparent erroneous report of multiporate conceptacles in the original description; and that the holotype comprises at least two heterotypic elements. Foslie (1906) described this species as Phymatolithon muricatum based on material collected by Yendo at Botany Beach, near Port Renfrew on Vancouver Island, Canada in June, 1901. Foslie's original description included that the thallus habit was thick, up to $4 \mathrm{~mm}$, partly smooth and loosens easily from the substratum. Anatomically the species had a well- developed hypothallus with upswept arcs of cells. Sporangial conceptacles were 200-300 $\mu \mathrm{m}$ diameter with 12 roof pores. Thalli were reported to occur on rocks and mussel shells. De Toni (1924: 662) transferred the species to Lithothamnion Phillipi. Mason (1953) added information about the epithallium (2-3 cell layers with cells 5-6 $\mu \mathrm{m}$ wide and 3$4 \mu \mathrm{m}$ tall) and cystocarpic conceptacles $(40-60 \mu \mathrm{m}$ diameter and 30-40 $\mu \mathrm{m}$ tall often embedded in the thallus), and she repeated Foslie's description of multiporate sporangial conceptacles. She photographed some of the specimens from TRH (Mason 1953, Pl. 32a \& b) and noted that a fragment of the type material was in UC (UC 341316). Adey (1970) examined type material in TRH and reported finding no asexual (bi/tetrasporangial) conceptacles nor conceptacle primordial caps characteristic of Phymatolithon Foslie, but stated that "... the anatomy is peculiar in a number of ways, and some doubt remains." 


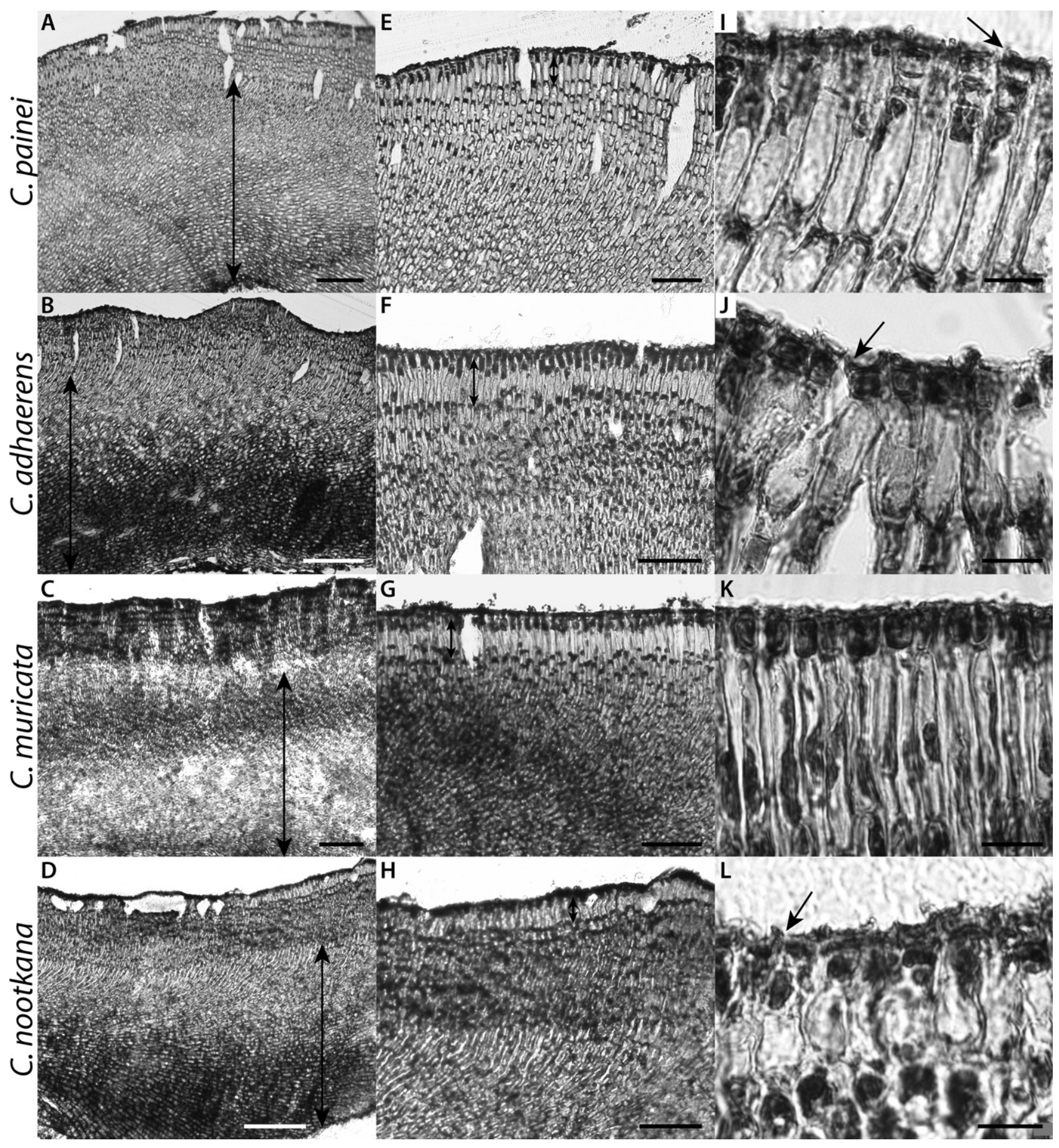

FIG. 6. Cross-sections of Crusticorallina species, depicting (A-D) thick hypothalli of C. painei (GWS020983), C. adhaerens (GWS020762), C. muricata (PTM1220), and C. nootkana (UBC A88650); (E-H) elongated meristematic cells of C. painei (GWS020983), C. adhaerens (GWS019429), C. muricata (GWS013078), and C. nootkana (UBC A88650); and (I-L) epithallial cells flared in C. painei (GWS020983), flared in C. adhaerens (GWS021681), unflared in C. muricata (GWS010132), and flared in C. nootkana (GWS010093). Scales $=$ (A-D) $100 \mu \mathrm{m},(\mathrm{E}-\mathrm{H}) 50 \mu \mathrm{m},(\mathrm{I}-\mathrm{L}) 10 \mu \mathrm{m}$.

Steneck and Paine (1986) transferred Phymatolithon muricatum to Pseudolithophyllum Me. Lemoine following Adey's concept of Pseudolithophyllum based on a spurious lectotype (Silva et al. 1996: 269) and not Lemoine's (1978) revised concept. Currently
Pseudolithophyllum, with P. fuegianum (Heydrich) M.L.Mendoza \& Cabioch as the generitype, is considered a synonym of Lithophyllum Phillipi (Silva et al. 1996: 269). Steneck and Paine (1986) clearly described and illustrated material that they 
considered to belong to this species, including its habit, thick and lobate with distinct white margins, gently undulating surfaces, and common crescentshaped swirls, its anatomy with flared epithallial cells, very elongate meristematic cells and a thick hypothallus, and its reproduction with buried conceptacle primordia and Phymatolithon-shaped conceptacles. Taxonomically, they recognized that Lithophyllum lichenare L.R.Mason was conspecific with $P$. muricatum, and designated one of two specimen fragments in UC as the lectotype, UC 341316 (D) apparently because, "Other Foslie syntypes are referable to Pseudolithophyllum whidbeyense and Lithophyllum impressum."

The holotype collection in TRH A3-148 comprises numerous specimens and fragments, in two boxes, some thick and epilithic and some thin on Mytilus sp. shells. DNA sequencing of some of these specimens indicates at least two distinct species are present, one of which represents an undescribed species in another genus (Gabrielson, personal observation). According to Article 9.14 of the ICN (McNeill et al. 2012), "When a type... contains parts belonging to more than one taxon... the name must remain attached to the part... that corresponds most nearly with the original description or diagnosis." It appears that Steneck and Paine (1986) recognized that more than one taxon comprised the holotype (they used the term syntype, see quote in previous paragraph), and designated the specimen in UC that they examined as the lectotype (UC 341316 (D)). This specimen conforms most closely to the original description, being thick and with a strongly developed hypothallus and with conceptacles that fall within the range given by Foslie (1906). Like Adey (1970) and Steneck and Paine (1986) we observed no multiporate conceptacles in any of the material in TRH or UC. We concur with the lectotype designation first made by Steneck and Paine (1986) and in accordance with Article 9.19 of the ICN (McNeill et al. 2012) we follow that designation. The partial $r b c \mathrm{~L}$ sequence we obtained from UC 341316 is identical to field collected material that we call C. muricata.

Despite Steneck and Paine's (1986) clear description of C. muricata (as P. muricatum), we are uncertain that all of the material that they examined belongs to this species due to recognition of three other species in this genus whose distributions overlap much of the range of C. muricata and the absence of distinguishing morpho-anatomical features among them. Moreover, the specimen from Torch Bay, AK is over $600 \mathrm{~km}$ north of our northernmost DNA confirmed site for C. muricata. Without sequencing type material we would not know to which of the species of Crusticorallina the lectotype belonged.

Crusticorallina nootkana G.W.Saunders, Martone, K.R.Hind, C.P.Jensen, \& P.W.Gabrielson sp. nov.
Etymology: Named after Nootka Sound on Vancouver Island, BC, the center of its known biogeographic distribution.

Holotypus: UNB GWS010093.

Type Locality: Island south of Clotchman Island, Spanish Pilot Group, Tahsis, BC, Canada, 23 May 2008, on bedrock, $20 \mathrm{~m}$ depth, leg. G. W. Saunders.

Description: Thallus encrusting, smooth, around $420 \mu \mathrm{m}$ thick, white margin thin $(0.35 \mathrm{~mm}$ wide, Fig. 5, D and H), sometimes nonadherent and leafy; white swirls not seen on its surface; epithallial cells 4.9-7.0 $\mu \mathrm{m}$ tall, always flared distally to $8.9 \mu \mathrm{m}$ wide (Fig. 6L); perithallus around $115 \mu \mathrm{m}$ thick (Fig. 6, $\mathrm{D}$ and $\mathrm{H}$ ); hypothallus around $300 \mu \mathrm{m}$ thick (Fig. 6D); conceptacles not observed; $r b c \mathrm{~L}, p s b \mathrm{~A}$ and COI-5P sequences diagnostic (See Table S3, Appendix S1).

Habit and Habitat: On bedrock; low intertidal, particularly under Phyllospadix spp. (surfgrass) and subtidally to $20 \mathrm{~m}$ depth on exposed shores.

Distribution: Kyuquot, Vancouver Island south to Botany Beach, Vancouver Island, BC, Canada (Fig. 4).

Comments: Crusticorallina nootkana is perhaps the easiest species to distinguish by its thinner crust (Table S3), wider epithallial cells (Table S3), commonly nonadherent margin (Fig. $5 \mathrm{H}$ ), and narrow biogeographic distribution (Fig. 4). Crusts with thalli thicker than $420 \mu \mathrm{m}$ are unlikely to be C. nootkana (Table S3). One of our collections of C. nootkana had a leafy, shelf-like, nonadherent margin (Fig. $5 \mathrm{H}$ ), but it is difficult to know if this morphology is common given the small sample size.

\section{DISCUSSION}

Placement of Crusticorallina in subfamily Corallinoideae. Hind and Saunders (2013) first demonstrated that four different species, all nongeniculate corallines that they called $P$. muricatum, belonged in the tribe Corallineae, a tribe and subfamily (Corallinoideae) previously considered to include only geniculate taxa. In their dataset, Hind and Saunders (2013) did not include Neogoniolithon Setchell \& L.R.Mason, hypothesized by Cabioch $(1972,1988)$ to be sister to Corallinoideae based on morpho-anatomical characters and subsequently supported by the phylogenetic analyses of Bailey et al. (2004) and Bittner et al. (2011). Furthermore, they did not ascertain which, if any, of the four species that they called $P$. muricatum was indeed that species by comparing DNA sequences from their collections to sequences from type specimens. Using SSU sequence data from GenBank, we have confirmed the placement of $P$. muricatum spp. (as Crusticorallina) within the subfamily Corallinoideae (and tribe Corallineae; Fig. 1). Crusticorallina resolved as distinct from the subfamily Neogoniolithoideae, which contains Neogoniolithon and at least the generitype of Spongites Kützing, S. fruticulosa Kützing (Rösler et al. 
2016). We also sequenced the lectotype specimen of Phymatolithon muricatum, basionym of Crusticorallina muricata, confirming to which of the four species called P. muricatum by Hind and Saunders (2013) that name belongs.

Hind and Saunders (2013) pointed out that there are no morpho-anatomical characters that distinguish Neogoniolithoideae from Corallinoideae, and we concur, even with a more complete characterization of Crusticorallina, the only nongeniculate taxon of Corallinoideae. Neogoniolithoideae and Corallinoideae share in common the three reproductive features that were used by Kato et al. (2011) to segregate subfamilies formerly all grouped in Mastophoroideae (e.g., Neogoniolithoideae, Porolithoideae, Hydrolithoideae), namely: (i) spermatangia borne on the floor and walls of male conceptacles, (ii) gonimoblast filaments that arise from the dorsal and/or marginal surfaces of the fusion cell, and (iii) tetrasporangial conceptacles formed by filaments peripheral to the fertile area (Type 1). The vegetative characters diagnostic for all species of Crusticorallina, an encrusting habit, a relatively thick thallus with a hypothallus comprising $50 \%-80 \%$ of total thallus thickness, elongate medullary cells and absence of trichocytes are all characters shared by at least some species of Neogoniolithon (Penrose 1996, Kato et al. 2013, Mateo-Cid et al. 2014), although we have not found in the literature a single species in that genus that exhibits this entire suite of characters. Moreover, species concepts in Neogoniolithon are in a state of flux (Kato et al. 2013). Species are difficult to distinguish by morpho-anatomy (MateoCid et al. 2014), no species in the genus has been linked to its type specimen by DNA sequence and names are applied with little regard for biogeography (Sissini et al. 2014). Yet in all phylogenetic analyses to date, including the most recent and comprehensive five marker analysis by Rösler et al. (2016), Neogoniolithoideae and Corallinoideae occur as distinct, well-supported clades that may or may not be sister taxa. Thus, we continue to recognize Corallinoideae and Neogoniolithoideae as distinct monophyletic subfamilies.

Crusticorallina species discrimination. Distinguishing among the four species of Crusticorallina using ecology and/or morpho-anatomy is nearly impossible, in part because they are uncommon and difficult to collect. This is reflected in our low sample sizes (mostly fewer than 10 specimens per species) despite years of collecting in low intertidal habitats mainly in WA and southern BC (by PWG and PTM) and more recently collecting subtidally by SCUBA in central and northern BC (by GWS and KRH). Because of low sample sizes, the following comparisons to segregate species should be used with caution. Crusticorallina nootkana is perhaps the easiest to distinguish by its thinner crust, wider epithallial cells, commonly nonadherent margin, and narrow biogeographic distribution; C. muricata by the absence or rare occurrence of flared epithallial cells, a feature present in all other species; C. $a d$ haerens by its epizoic or nonepilithic habit (once even found growing on glass bottle), however, C. $a d$ haerens also occurs epilithically and then cannot be distinguished from C. painei or possibly the other species. Based on these observations, it is possible that some of the field-collected material identified as P. muricatum in previous studies (e.g., Steneck and Paine 1986, McCoy 2013, McCoy and Pfister 2014) may have been one of these other species. For example, Steneck and Paine (1986) indicated that in their samples of P. muricatum, epithallial cells were "somewhat angular (symmetrical trapezoid) and tapering toward the meristem." These "flared" epithallial cells (as referred to here) were typically absent $(12 \%)$ in our C. muricata specimens, but present $(100 \%)$ in all other species of Crusticorallina.

Failure of morpho-anatomy to delineate coralline taxa. No coralline morpho-anatomist ever proposed, or likely ever suspected, that P. muricatum belonged in the subfamily Corallinoideae, perhaps representing the most significant failure of morpho-anatomy to provide characters useful to distinguish corallines at any taxonomic rank without supporting DNA sequence evidence. This failure of morpho-anatomy to correctly delimit both geniculate and nongeniculate taxa in the Corallinales and Hapalidiales has been especially evident in the North Pacific Ocean, where in the last 5 years two new genera have been erected, Johansenia (Hind and Saunders 2013) and Callilithophytum P.W.Gabrielson, W.H.Adey, G.P.Johnson, \& Hernandez-Kantun (Adey et al. 2015); one genus resurrected, Neopolyporolithon W.H.Adey \& H.W.Johansen (Adey et al. 2015); four genera placed in synonymy in Corallina LinnaeusMarginisporum (Yendo) Ganesan, Serraticardia (Yendo) P.C.Silva (Hind and Saunders 2013), Pachyarthron Manza (Hind et al. 2014a) and Yamadaia Segawa (Martone et al. 2014); and numerous species transferred to other genera, Calliarthron yessoense (Yendo) Manza to Alatocladia (Yendo) H.W.Johansen (Gabrielson et al. 2011), Yamadaia americana E.Y.Dawson \& R.L. Steele to Chiharea H.W.Johansen (Martone et al. 2014); Pseudolithophyllum decipiens (Foslie) Steneck \& R.T.Paine to Spongites (Van der Merwe et al. 2015) and Corallina frondescens Postels \& Ruprecht to Bossiella P.C.Silva (Hind et al. 2015). Worldwide, all coralline genera and species need to be reassessed with DNA sequence data to determine which morpho-anatomical characters are taxonomically meaningful and at what ranks.

Coralline endemism in the Northeast Pacific Ocean. Even with the renewed interest in coralline systematics worldwide driven by DNA sequence data and new genera and species being recognized, e.g., in the subarctic (Adey et al. 2015), Europe (Walker et al. 2009, Pardo et al. 2013, Hernandez-Kantun et al. 2015, Peña et al. 2015), Japan (Kato et al. 
2011, Kato et al. 2013), the Red Sea (Basso et al. 2015), New Zealand (Broom et al. 2008, Nelson et al. 2015), and South Africa (Van der Merwe et al. 2015), the NE Pacific is proving to be a center of endemism for both geniculate and nongeniculate coralline genera. Thus far, four geniculate genera are endemic: Calliarthron Manza (Gabrielson et al. 2011), Chiharaea (Martone et al. 2012), Johansenia (Hind and Saunders 2013), and Lithothrix J.E.Gray; and two nongeniculate genera are endemic: Callilithophytum (Adey et al. 2015), the obligate epiphyte on Calliarthron tuberculosum (Postels \& Ruprecht) Manza, and, herein, Crusticorallina. At present, no other region worldwide boasts this number of endemic coralline genera, not even New Zealand or Australia, both well known for their marine algal endemics (Womersley 1981, Nelson 2013). The underlying cause for this diversification in coralline algal genera in the NE Pacific remains unknown.

Genicula and conceptacle placement. Crusticorallina is distinct, thus far, from all other taxa in the subfamily Corallinoideae by lacking genicula and bearing conceptacles in its crust. There appears to be an evolutionary advantage to having reproductive structures (conceptacles) in intergenicula, as even when the crustose base is far more extensive in area than the geniculate axes, as occurs in some species of Chiharaea, conceptacles are borne only on the erect axes (Martone et al. 2012). This is true for all geniculate corallines, even though genicula are not all homologous, having arisen at least three different times from different crustose coralline ancestors in the subfamilies Corallinoideae, Lithophylloideae, and Metagoniolithoideae (Bailey and Chapman 1998, Bittner et al. 2011, Rösler et al. 2016). Moreover, our data demonstrate that Crusticorallina species evolved from geniculate coralline ancestors (Fig. 2), representing a complete evolutionary reversal and a return to a crustose morphology similar to other nongeniculate corallines at the base of the coralline phylogeny (Bailey and Chapman 1998, Bittner et al. 2011). Given the repeated evolution of genicula from crustose coralline ancestors, past researchers have speculated that erect, geniculate fronds may be adaptations for increasing spore dispersal (Johansen 1981), increasing light competition (Johansen 1981), or perhaps decreasing herbivory (Padilla 1984) as documented for branched crusts (Steneck 1983, 1986). However, adaptive arguments are difficult to maintain when nongeniculate species, such as Crusticorallina spp., can persist and even radiate despite having lost geniculate fronds altogether.

We thank Laura Anderson, Bridgette Clarkston, Kyatt Dixon, Aaron Galloway, Sarah Hamsher, Ted Klenk, Dan McDevit, Kevin Miklasz, Kathryn Roy, Kevin Britton-Simmons, Jackie Sones, H. Stewart, and Scott Toews, for collections. Gary
Saunders provided many collections, including two holotype specimens; we sincerely appreciate his contributions to this project. Collections made by Sandra Lindstrom were supported by funding from Cook Inlet Regional Citizens Advisory Council, Hart Crowser, and Natural Sciences and Engineering Research Council (NSERC) and were facilitated by Amy Deveau, Jochen Halfar, Jonathan Houghton, Susan Saupe, and Nancy Turner. We thank the Makah Tribal Council for access to Tatoosh Island. We thank Craig Schneider for advice regarding taxonomic nomenclature. KRH and PTM thank the Hakai Institute for their contribution of funding and access to outstanding research facilities along the central coast of BC, Canada. Wilson Freshwater, DNA Analysis Core Facility, University of North Carolina, Wilmington provided sequencing support and Todd Vision provided research space and equipment to PWG. A portion of this study was done while PWG was a visiting professor at the Friday Harbor Laboratories, University of Washington. This research was funded in part by a NSERC grant to PTM and by a family trust to PWG.

Adey, W. H. 1970. A revision of the Foslie crustose coralline herbarium. Det. Kong. Norske Vidensk. Selsk. Skr. 1:1-46.

Adey, W. H., Hernandez-Kantun, J. J., Johnson, G. \& Gabrielson, P. W. 2015. DNA sequencing, anatomy and calcification patterns support a monophyletic, subarctic, carbonate reef-forming Clathromorphum (Hapalidiaceae, Corallinales, Rhodophyta). J. Phycol. 51:189-203.

Adey, W. \& Johansen, H. W. 1972. Morphology and Taxonomy of Corallinaceae with special reference to Clathromorphum, Mesophyllum and Neopolyporolithon gen. nov. Phycologia 11:159-80.

Areschoug, J. E. 1852. Ordo XII. Corallineae. In Agardh, J. G. [Ed.] Species genera et ordines algarum... Volumen secundum: algas florideas complectens. C.W.K. Gleerup, Lund, Sweden, pp. 506-76.

Bailey, J. C. \& Chapman, R. L. 1998. A phylogenetic study of the Corallinales (Rhodophyta) based on nuclear small-subunit rRNA gene sequences. J. Phycol. 34:692-705.

Bailey, J. C., Gabel, J. E. \& Freshwater, D. W. 2004. Nuclear 18S rRNA gene sequence analyses indicate that the Mastophoroideae (Corallinaceae, Rhodophyta) is a polyphyletic taxon. Phycologia 43:3-12.

Basso, D., Caragnano, A., Le Gall, L. \& Rodondi, G. 2015. The genus Lithophyllum in the north-western Indian Ocean, with description of $L$. yemenense sp. nov., $L$. socotraense sp. nov., $L$. subplicatum comb. et stat. nov., and the resumed $L$. affine, $L$. kaiseri and L. subreduncum (Rhodophyta, Corallinales). Phytotaxa 208:183-200.

Bittner, L., Payri, C., Mandeveldt, G., Couloux, A., Cruaud, C., Reviers, B. \& Le Gall, L. 2011. Evolutionary history of the Corallinales (Corallinophycidae, Rhodophyta) inferred from nuclear, plastidial and mitochondrial genomes. Mol. Phylogenet. Evol. 61:697-713.

Broom, J. E. S., Hart, D. R., Farr, T. J., Nelson, W. A., Neill, K. F., Harvey, A. S. \& Woelkerling, W. J. 2008. Utility of $p s b \mathrm{~A}$ and nSSU for phylogenetic reconstruction in the Corallinales based on New Zealand taxa. Mol. Phylo. Evol. 46:958-73.

Cabioch, J. 1971. Essai d'une nouvelle classification des Corallinacées actuelles. Compte Rendu Hebdomadaire des Séances de l'Académie des Sciences. Paris. Série D 272:1616-9.

Cabioch, J. 1972. Étude sur les Corallinacées. II - La morphogenèse: conséquences systématiques et phylogénétiques. Cah. Biol. Mar. 13:137-288.

Cabioch, J. 1988. Morphogenesis and generic concepts in coralline algae. Helgolander Meeresunters 42:493-509.

Clarkston, B. E. \& Saunders, G. W. 2012. An examination of the red algal genus Pugetia (Kallymeniaceae, Gigartinales) with descriptions of Salishia firma gen. \& comb. nov., Pugetia cryptica sp. nov. and Beringia wynnei sp. nov. Phycologia 51:33-61. 
Darriba, D., Taboada, G. L., Doallo, R. \& Posada, D. 2012. jModelTest 2: more models, new heuristics and parallel computing. Nat. Methods 9:772.

De Toni, G. B. 1924. Sylloge algarum omnium hucusque cognitarum. Vol. IV. Florideae. Sectio V. Additamenta. Sumptibus auctoris, Patavii [Padua], 767 pp.

Foslie, M. 1906. Den Botaniske Sammlung. Det. Kong. Norske Vidensk. Selsk. Skr. 1905:17-24.

Foster, M. S. 1975. Algal succession in a Macrocystis pyrifera forest. Mar. Biol. 32:313-29.

Freshwater, D. \& Rueness, J. 1994. Phylogenetic relationships of some European Gelidium (Gelidiales, Rhodophyta) species, based on $r b c \mathrm{~L}$ nucleotide sequence analysis. Phycologia 33:187-94.

Gabrielson, P. W., Miller, K. A. \& Martone, P. T. 2011. Morphometric and molecular analyses confirm two species of Calliarthron (Corallinales, Rhodophyta), a genus endemic to the northeast Pacific. Phycologia 50:298-316.

Harper, J. T. \& Saunders, G. W. 2001. The application of seuqences of the ribosomal cistron to the systematics and classification of the florideophyte algae (Florideophyceae, Rhodophyta). Cah. Biol. Mar. 42:25-38.

Harvey, A., Woelkerling, W., Farr, T., Neill, K. \& Nelson, W. 2005. Coralline algae of central New Zealand: an identification guide to common 'crustose' species. NIWA Information Series $57: 145$.

Hernandez-Kantun, J. J., Rindi, F., Adey, W. H., Heesch, S., Peña, V., Le Gall, L. \& Gabrielson, P. W. 2015. Sequencing type material resolves the identity and distribution of the generitrype Lithophyllum incrustans, and related European species $L$. hibernicum and L. bathyporum (Corallinales, Rhodophyta). J. Phycol. 51:791-807.

Hind, K. R., Gabrielson, P. W., Lindstrom, S. C. \& Martone, P. T. 2014a. Misleading morphologies and the importance of sequencing type specimens for resolving coralline taxonomy (Corallinales, Rhodophyta): Pachyarthron cretaceum is Corallina officinalis. J. Phycol. 50:760-4.

Hind, K. R., Gabrielson, P. W. \& Saunders, G. W. 2014b. Molecular-assisted alpha taxonomy reveals pseudocryptic diversity among species of Bossiella (Corallinales, Rhodophyta) in the eastern Pacific Ocean. Phycologia 53:443-56.

Hind, K. R., Miller, K. A., Young, M., Jensen, C., Gabrielson, P. W. \& Martone, P. T. 2015. Resolving cryptic species of Bossiella (Corallinales, Rhodophyta) using contemporary and historical DNA. Am. J. Bot. 102:1-19.

Hind, K. R. \& Saunders, G. W. 2013. A molecular phylogenetic study of the tribe Corallineae (Corallinales, Rhodophyta) with an assessment of genus-level taxonomic features and descriptions of novel genera. J. Phycol. 49:103-14.

Huelsenbeck, J. P. \& Ronquist, F. 2001. MRBAYES: Bayesian inference of phylogenetic trees. Bioinformatics 17:754-5.

Johansen, H. W. 1969. Morphology and systematics of coralline algae with special reference to Calliarthron. Univ. Cal. Pub. Bot. 49:1-98.

Johansen, H. W. 1974. Articulated coralline algae. Oceanogr. Mar. Biol. Ann. Rev. 12:77-127.

Johansen, H. W. 1981. Coralline Algae, a First Synthesis. CRC Press, Boca Raton, Florida, 239 pp.

Kato, A., Baba, M. \& Suda, S. 2011. Revision of the Mastophoroideae (Corallinales, Rhodophyta) and polyphyly in nongeniculate species widely distributed on Pacific coral reefs. $J$. Phycol. 47:662-72.

Kato, A., Baba, M. \& Suda, S. 2013. Taxonomic circumscription of heterogeneous species Neogoniolithon brassica-florida (Corallinales, Rhodophyta) in Japan. Phycol. Res. 61:15-26.

Kearse, M., Moir, R., Wilson, A., Stones-Havas, S., Cheung, M., Sturrock, S., Buxton, S. et al. 2012. Geneious Basic: an integrated and extendable desktop software platform for the organization and analysis of sequence data. Bioinformatics 28:1647-9.

Kucera, H. \& Saunders, G. W. 2012. A survey of Bangiales (Rhodophyta) based on multiple molecular markers reveals cryptic diversity. J. Phycol. 48:869-82.
Le Gall, L., Payri, C. E., Bittner, L. \& Saunders, G. W. 2010. Multigene phylogenetic analyses support recognition of the Sporolithales ord. nov. Mol. Phylogenet. Evol. 54:302-5.

Le Gall, L. \& Saunders, G. W. 2010. DNA barcoding is a powerful tool to uncover algal diversity: a case study of the Phyllophoraceae (Gigartinales, Rhodophyta), in the Canadian flora. J. Phycol. 46:374-89.

Lemoine, M. 1913. Mélobésiées. Revision des Mélobésiées antarctiques. In Anon [Ed.] Deuxième Expédition Antarctique Française (1908-1910) commandée par le Dr. Jean Charcot, Sciences Naturelles: Documents Scientifiques, Botanique, Vol. 1. Masson \& Cie, Paris, pp. 1-67.

Lemoine, P. 1978. Typification du genre Pseudolithophyllum Lemoine. Rev. Algol. N. S. 13:117.

Littler, M. M. 1972. The crustose Corallinaceae. Oceanogr. Mar. Biol. Ann. Rev. 10:311-47.

Martone, P. T., Lindstrom, S. C., Miller, K. A. \& Gabrielson, P. W. 2012. Chiharaea and Yamadaia (Corallinales, Rhodophyta) represent reduced and recently derived articulated coralline morphologies. J. Phycol. 48:859-68.

Mason, L. R. 1953. The crustaceous coralline algae of the Pacific coast of the United States, Canada and Alaska. Univ. Cal. Publ. Bot. 26:313-89.

Mateo-Cid, L. E., Mendoza-Gonzalez, A. C. \& Gabrielson, P. W. 2014. Neogoniolithon (Corallinales, Rhodophyta) on the Atlantic coast of Mexico, including N. siankanensis sp. nov. Phytotaxa. 190:64-93.

McCoy, S. J. 2013. Morphology of the crustose coralline alga Pseudolithophyllum muricatum (Corallinales, Rhodophyta) responds to 30 years of ocean acidification in the northeast Pacific. $J$. Phycol. 49:830-7.

McCoy, S. J. \& Pfister, C. A. 2014. Historical comparisons reveal altered competitive interactions in a guild of crustose coralline algae. Ecol. Lett. 17:475-83.

McNeill, J., Barrie, F. R., Buck, W. R., Demoulin, V., Greuter, W., Hawksworth, D. L., Herendeen, P. S. et al. 2012. International Code of Nomenclature for Algae, Fungi, and Plants (Melbourne Code) adopted by the Eighteenth International Botanical Congress Melbourne, Australia, July 2011. Reg. Veg. 154:1-240.

Nelson, W. A. 2013. New Zealand Seaweeds. An Illustrated Guide. Te Papa Press, Wellington, 328 pp.

Nelson, W. A., Sutherland, J. E., Farr, T. J., Hart, D. R., Neill, K. T., Kim, H. J. \& Yoon, H. S. 2015. Multi-gene phylogenetic analyses of New Zealand coralline algae: Corallinapetra novaezelandiae gen. et sp. nov. and recognition of the Hapalidiales ord. nov. J. Phycol. 51:454-68.

Padilla, D. K. 1984. The importance of form: differences in competitive ability, resistance to consumers and environmental stress in an assemblage of coralline algae. J. Exp. Mar. Biol. Ecol. 79:105-27.

Paine, R. T. 1984. Ecological determinism in the competition for space. Ecology 65:1339-48.

Pardo, C., Lopez, L., Peña, V., Hernández-Kantún, J., Le Gall, L., Bárbara, I. \& Barreiro, R. 2013. A multilocus species delimitation reveals a striking number of species of coralline algae forming maerl in the OSPAR maritime area. PLoS ONE 9: e104073.

Peña, V., De Clerck, O., Afonso-Carrillo, J., Ballesteros, E., Bárbara, I., Barreiro, R. \& Le Gall, L. 2015. An integrative systematic approach to species diversity and distribution in the genus Mesophyllum (Corallinales, Rhodophyta) in Atlantic and Mediterranean Europe. Eur. J. Phycol. 50:1-15.

Penrose, D. L. 1996. Genus Neogoniolithon Setchell \& Mason 1943:90. In Womersley, H. B. S. [Ed.] The Marine Benthic Flora of Southern Australia. Rhodophyta. Part IIIB, Gracilariales, Rhodymeniales, Corallinales, and Bonnemaisoniales. Australian Biological Resources Study, Canberra, pp. 280-3.

Robba, L., Russell, S. J., Barker, G. L. \& Brodie, J. 2006. Assessing the use of the mitochondrial COX1 marker for use in DNA barcoding of red algae (Rhodophyta). Am. J. Bot. 93:1101-8.

Rösler, A., Perfectti, F., Peña, V. \& Braga, J. C. 2016. Phylogenetic relationships of Corallinaceae (Corallinales, Rhodophyta): 
taxonomic implications for reef-building corallines. J. Phycol. 52:412-431.

Saunders, G. W. 2008. A DNA barcode examination of the red algal family Dumontiaceae in Canadian waters reveals substantial cryptic species diversity. 1. The foliose Dilsea - Neodilsea complex and Weeksia. Botany 86:773-89.

Silva, P. C., Basson, P. W. \& Moe, R. L. 1996. Catalogue of the benthic marine algae of the Indian Ocean. Univ. Cal. Publ. Bot. 79:1-1259.

Silvestro, D. \& Michalak, I. 2012. raxmlGUI: a graphical front-end for RAxML. Org. Divers. Evol. 12:335-7.

Sissini, M. N., Oliveira, M. C., Gabrielson, P. W., Robinson, N. M., Okolodkov, Y. B., Rodriguez, R. R. \& Horta, P. A. 2014. Mesophyllum erubescens (Corallinales, Rhodophyta)-so many species in one epithet. Phytotaxa 190:299-319.

Smith, S. V. 1972. Production of calcium carbonate on the mainland shelf of southern California. Limnol. Oceanogr. 17:28-41.

Stearn, C. W., Scoffin, T. P. \& Martindale, W. 1977. Calcium carbonate budget of a fringing reef on the west coast of Barbados. Bull. Mar. Sci. 27:479-510.

Steneck, R. S. 1983. Escalating herbivory and resulting adaptive trends in calcareous algal crusts. Paleobio. 9:44-61.

Steneck, R. S. 1986. The ecology of coralline algal crusts: convergent patterns and adaptive strategies. Ann. Rev. Ecol. Syst. 17:273-303.

Steneck, R. S. \& Paine, R. T. 1986. Ecological and taxonomic studies of shallow-water encrusting Corallinaceae (Rhodophyta) of the boreal northeastern Pacific. Phycologia 25:22140.

Thiers, B. 2016. (continuously updated) Index Herbariorum: A global directory of public herbaria and associated staff. New York Botanical Garden's Virtual Herbarium. Available at http://sweetgum.nybg.org/ih/ accessed 9 July, 2016.

Van der Merwe, E., Miklasz, K., Channing, A., Maneveldt, G. W. \& Gabrielson, P. W. 2015. DNA sequencing resolves species of Spongites (Corallinales, Rhodophyta) in the Northeast Pacific and South Africa, including S. agulhensis sp. nov. Phycologia 54:471-90.

Walker, R. H., Brodie, J., Russell, S., Irvine, L. M. \& Orfanidis, S. 2009. Biodiversity of coralline algae in the northeastern Atlantic Including Corallina caespitosa sp. nov. (Corallinoideae, Rhodophyta). J. Phycol. 45:287-97.

Womersley, H. B. S. 1981. Biogeography of Australasian marine macroalgae. In Clayton, M. N. \& King, R. J. [Eds.] Marine Botany: An Australasian Perspective. Longman Cheshire, Melbourne, pp. 290-307.

Wynne, M. J. \& Saunders, G. W. 2012. Taxonomic assessment of North American species of the genera Cumathamnion,
Delesseria, Membranoptera and Pantoneura (Delesseriaceae, Rhodophyta) using molecular data. Algae 27:155-73.

Yoon, H. S., Hackett, J. D. \& Bhattacharya, D. 2002. A single origin of the peridinin and fucoxanthin containing plastids in dinoflagellates through tertiary endosymbiosis. Proc. Natl. Acad. Sci. USA 99:11724-9.

\section{Supporting Information}

Additional Supporting Information may be found in the online version of this article at the publisher's web site:

Figure S1. Phylogram inferred by maximum likelihood (ML) analysis of COI-5P sequence data (539 bp).

Figure S2. Phylogram inferred by maximum likelihood (ML) analysis of psbA sequence data (778 bp).

Figure S3. Phylogram inferred by maximum likelihood (ML) analysis of $\mathrm{rbcL}$ sequence data $(1,278 \mathrm{bp})$.

Table S1. List of Crusticorallina specimens, including collection details, herbarium accession numbers, and GenBank numbers.

Table S2. List of SSU, CO1-5P, psbA, and rbcL sequences used in the concatenated and SSU rDNA trees.

Table S3. Summary of morphology and habitat assessment of Crusticorallina species examined in this study.

Appendix S1. Distance matrices indicating percent divergence of four genes used to discriminate Crusticorallina species. 